\title{
HEDONIC, UTILITARIAN AND SYMBOLIC DRIVES BEHIND PLACE CHECK-IN ACTIVITY OF MOBILE CONSUMERS
}

\author{
Şahika Burçin TATAR ${ }^{[*]}$ \\ İrem Eren ERDOĞMUŞ ${ }^{[*]}$
}

\begin{abstract}
Turkey with 67 million mobile subscribers is an important target market for mobile marketers. Check-in applications which is an important part of mobile marketing are the main subject of this study. The aim of the study is to measure the the impacts of hedonic, utilitarian and social motivations behind mobile check-in activity, along with the impact of familiarity with check-in application and socialiability level of a person. These impacts are examined over frequency of check-ins and loyalty to a specific mobile check-in application. The relationships were tested with Structural Equation Modeling (SEM) by using Amos 21 software program. The outcomes show positive effects of familiarity with check-in application on check-in frequency; hedonic, utilitarian, conspicuous values and socialiability on loyalty to a specific check-in application. The results of the study is believed to be helpful to mobile marketing managers in terms of crafting right marketing strategies in mobile environment.
\end{abstract}

Keywords: Mobile marketing, Consumer behaviour, Location based applications, Check-in applications.

\section{MOBİL TÜKETİCININN YER BİLDİRIMİ YAPMA DAVRANIȘINDA HAZCI, FAYDACI VE SOSYAL MOTIVASYONLAR}

Öz

Türkiye, 67 milyon cep telefonu abonesi ile mobil pazarlama için önemli bir hedef pazardır. Bu araştırmanın ana konusu mobil pazarlamanın önemli bir parçası olan yer bildirimi (check-in) uygulamalarıdır. Çalışmanın amacı, mobil yer bildirimi yapma davranışına hazcı, faydacı ve sosyal motivasyonların etkileri ile beraber kişinin yer bildirimi uygulamasına olan aşinalığı ve sosyalleșebilirlik düzeyinin etkilerini ölçmektir. Bu etkiler, yer bildirimi yapma sıklığı ve belirli bir mobil yer bildirimi uygulamasına olan sadakat üzerinden incelenir. İlişkiler Yapısal Eşitlik Modellemesi (SEM) ile Amos 21 yazılım programı kullanılarak test edilmiştir. Sonuçlar, aşinalığın yer bildirimi yapma sıklığına; hazcı, faydac1, sosyal değerler ve sosyalleșebilirliğin ise belirli bir check-in uygulamasına olan sadakat üzerinde

[*] Assoc. Prof., Marmara University, Faculty of Business Administration, sbtatar@gmail.com

[**] Marmara University, Faculty of Business Administration, ireme@marmara.edu.tr 
pozitif etkileri olduğunu göstermektedir. Çalışmanın sonuçlarının mobil pazarlama yöneticilerine mobil ortamda doğru pazarlama stratejileri hazırlamaları konusunda yardımcı olacağına inanılıyor.

Anahtar Kelimeler: Mobil pazarlama, tüketici davranışı, lokasyon bazlı uygulamalar, yer bildirimi uygulamaları

\section{Introduction}

Recent developments in global mobile communication technologies ensure an easy access to the Internet and social media anytime and anywhere (Bauer et al., 2005; Varnali and Toker, 2010). People can connect to the Internet with their smart phones or mobile devices and look for news while walking, or check for the weather while traveling, or buy or sell an item, or withdraw money from the bank, or find places with location based services (LBS). The change in technology and consumer behaviour pushed marketers to apply mobile marketing, which is defined as a form of marketing, advertising or sales promotion activity aimed at consumers and is conducted over a mobile channel (MMA, Mobile Marketing Association, 2003). This research concentrates on a widespread tool of mobile marketing, LBS (Virrantaus et al., 2001; Vasconcelos et al., 2012) and tries to explain the factors that affect consumer usage and loyalty.

LBS as a form of mobile marketing, works with mobile Internet and third generation $(3 \mathrm{G})$ mobile technology and helps people to connect with each other using geolocation. Consumers sign up for a LBS account and download an application for their smart phones. Then users can check-in, broadcasting their location to their friends. Check-ins are done in special venues, physical places such as restaurants, universities, or monuments. Check-in venues are visible to everybody whereas check-ins can be available to a large audience or kept as private (Scellato et al., 2011). People check-in for many different reasons; they inform friends and family, they do it for fun, they meet new friends, they share opinions and tips about places and so on (Vasconcelos et al., 2012).

There are only a limited number of studies on LBS, since the medium is quite new and in its introduction stage (Vasconcelos et al., 2012). Most of the existing studies, on the other hand, focus on user check-in dynamics (e.g., Tang, 2010; Lindqvist et al., 2011; Smith et al., 2005; Consolvo et al., 2005; Barkhuus et al., 2008; Ludford et al., 2008) to understand the consumer behaviour drivers and characteristics. This study is also in line with this stream of research, seeking an answer to 'why do people really check-in?' taking into consideration the impact of utilitarian, hedonic and symbolic values, familiarity with check-in applications and personal characteristic of socialiability on check-in frequency and loyalty to check-in application. Previous research indicate mainly the utilitarian and hedonic motivations of check-in activities (Consolvo et al. 2005; Smith et al., 2005; Ludford et al., 2007; Tang et al., 2010; Lindqvist et al., 2011). In addition to those values, this study incorporates symbolic values, familiarity with check-in applications, and socialiability as a consumer characteristics into the model to provide a wider perspective on the subject. Thus, the significance of the study is its wide content about people's check-in motivations 
and its discussion about brand loyalty to check-in applications. Another related significance is contribution to general studies on understanding how and why people use social media. The study is also conducted in an emerging market setting, where social media usage is an increasing rate, and the results may provide guidance to venue owners in marketing and communication.

The context of the study is chosen as Turkey because it has high potential for mobile marketers. According to the report of Institution of Turkish Information Technologies and Communications, there are approximately 67 million mobile subscribers in Turkey as of December 2014. 41 million of those subscribers are $3 \mathrm{G}$ users and 10 million of them are mobile Internet users (www.tk.gov.tr). Besides, according to Pew Research Centers's report (2010), mobile check-in application users in Turkey and in other countries have similarities in terms of demographics and this may help generalize the results of this study. In Turkey by 2014, there are over 35 million Internet users and approximately 36 millions active Facebook accounts. Internet usage rate in Turkey is $45 \%$ of the population. People spend 4,9 hours on the Internet from PC's and 1,9 hours from mobile devices. People spend approximately 2 hours and 32 minutes on social media (http://www.dijitalajanslar.com). According to Google, Turkey is also ranked the first in social media usage for 2014 (http://webrazzi.com).

\section{Check-in Applications}

Foursquare, later named as Swarm, is the prime example of LBS, along with Facebook Check-in, Gowalla, Google Latitude as some examples. As videos and images are the main objects of Youtube, as tweets are the main objects of Twitter and as photographs are the main objects of Instagram, one can claim that check-ins at venues are the main objects of LBS. The check-ins are awarded with points, badges, mayorships as well as receiving special promotions from brand owners. In some types of LBS, users can also make comments and leave tips in the venues that they check-in. Sharing is an ongoing process and a lot of subjective information is passed on to social media by users about places all the time. Some location-sharing platforms also allow for the creation of a brand user account, whereby companies can create their own content such as tips, comments, and photos, promoting themselves, their products and services. Special offers are also created to attract the attention of the users (Vasconcelos et al., 2012).

LBS can create three different types of interactions: firm-consumer interaction, consumer-firm interaction, and consumer-consumer interaction. In addition to LBS being a platform for firmconsumer interaction, special offers may also be made on the LBS to attract the attention of the users of this platform (Humphreys and Wilken, 2015). Study by Vasconcelos et al. (2012) also states that businesses may also post unrelated links at a large variety of venues to derive consumer traffic to their venue, and actually succeed in doing so. User-posted tips, on the other hand, mean that consumers are interacting with businesses, exposing the weaknesses and qualities about their business to everyone, including potential customers and competitors. Those tips can act as feedbacks collected from consumers, may help for opportunities for improvements, and impact the factors creating the future of the business. The check-in frequency also works like the 'like' 
button on facebook, expressing support and affective feelings towards the brand owners. Finally, the check-ins and tips of others affect the venue choice of consumers through a word-of-mouth effect (Cramer et al., 2011). Thus, the value of location-sharing is not tracking or communicating location, but lies on its potential to influence businesses, and consumers; it is about how it is read, used, viewed, and sometimes manipulated.

Check-in is usually a byproduct of many different purposes and also individual characteristics (Cramer et al., 2011). The extant literature has tried to identify some of these characteristics (e.g., Tang, 2010; Lindqvist et al., 2011; Smith et al., 2005; Consolvo et al., 2005; Barkhuus et al., 2008; Ludford et al., 2008) such as utility seeking, hedonic and social motivations. Thus, it is important for brand owners to understand what user motivations, capabilities, or characteristics drive check-in frequency, and then work on these drivers to induce more check-ins and possibly positive reviews on their venues.

Therefore, the aim of the study is to try and understand the consumer motivations behind the mobile check-in activity and examine how this activity may affect a business's life in a consumer driven manner. Another aim of this study is to try and guide businesses to manage and improve their consumer related marketing efforts better and more effectively.

\section{Hypotheses of the Study}

While developing the model, uses and gratifications theory was taken into consideration which is based on the idea that a media user seeks out a media source that best fulfills the needs of the user (Katz, Blumler and Gurevitch, 1974; Reinhard and Dervin, 2009). Uses and gratifications research show that the media users have different motivations to consume media and satisfy their needs such as social integration, entertainment, information, interaction with their media choices (Blanchflower and Watchravesringkan, 2014). According to LaRose and Eastin (2004), Internet usage has extended and challenged the uses and gratifications approach to understanding media attendance by discovering "new" gratifications and introducing powerful new explanatory variables. Mobile media, a comparatively new technology, has also revealed many uses and gratifications attached to them such as affection/socialiability, entertainment, instrumentality, psychological reassurance, status seeking (Leung and Wei, 2000). Furthermore, studies on social networking sites (SNS) utilized the uses and gratifications theory and showed a relationship between consumers motivations such as immediacy and interactivity and attitudes toward SNS (Muntinga, Moorman and Smit, 2011; Vrocharidou and Efthymiou, 2012; Oloo, 2013). This study similarly draws from uses and gratifications approach and expands with this new research area to understand the user behavior behind mobile check-in activity, by measuring the impact of tridimensional conceptualization of value (hedonic, utilitarian, symbolic). The uses and gratification approach acknowledges the individual characteristics as another variable that effects the differences in user responses to the same or similar media (Stone et al., 1999). Thus, interactivity inherent to social media usage and communication may emphasize the active role of socialiability, the tendency to affiliate and to prefer being with others (Santesso et al., 2004; Wadman et al., 2008; Rai, 2011), as an individual characteristic. 


\section{I. Impact of Hedonic, Utilitarian and Symbolic Values on Check-in Behaviour}

Grounded in consumer behaviour research that deals with attitudes towards products and services, it is suggested that consumer attitudes can be decomposed into a cognitive (utilitarian value that a person associates with the product or service) and an affective (hedonic value that a person associates with the product or service) component (Hirschman and Holbrook, 1982; Simonson et al., 2001). Furthermore, some marketers prefer a tridimensional conceptualization of consumer behaviour, adding the symbolic component (self-expression or social recognition) to cognitive and affective values. They argue that symbolic perceived value appears to be a fundamental dimension of consumption experience of products and services (Mathews, Ambroise and Brignier, 2011; Keller, 1993; Park, 1986).

Empirical studies suggest that both utilitarian value (Bauer et al., 2005; Kleijnen et al., 2007) and hedonic value contribute to consumer adoption of mobile marketing. Utilitarian consumption and thinking is directed by the logical, rational, cognitive thinking, correct choices, and is instrumental (Bazerman et al.,1998; Strahilcvitz and Myers, 1998; Dhar and Wertenbroch, 2000). Chiou (2004) and Chen et al. (2008) mention that technology usage such as mobile services increase users' utilitarian values. Studies show that people gain utilitarian values while using check-in applications such as place discovery, keeping track of places, informing friends and family and road assistance (Lindqvist et al., 2011; Ludford et al., 2007; Tang, 2010; Smith and Consolvo et al., 2005; Barkhuus et al., 2008; Ludford et al., 2008; Chiou, 2004; Chen et al., 2008). Thus the following hypotheses may be developed:

H1: Utilitarian user values have a significant and positive effect on check-in frequency.

H2: Utilitarian user values have a significant and positive effect on loyalty to a specific check in application.

Hedonic paradigm sees the consumer as an emotional and subjective person who tries to satisfy some experiential and intrinstic needs, seeking fun, amusement, fantasy, arousal, and sensual pleasure (Levy, 1959; Holbrook and Hirschman, 1982; Hanzaee et al., 2011). Studies on check-in application usage show that people's hedonistic values for check-in behaviour are social connection, tracking other people at the same place, and fun (Lindqvist et al., 2011; Smith and Consolvo et al., 2005; Barkhuus et al., 2008; Ludford et al., 2008). It is also found that the influence of hedonic value is stronger when compared to utilitarian value in building attitudes towards mobile technology in general (Bruner and Kumar, 2005) and especially among mobile users with low trust of mobile technology and low internet experience (Park and SuJin, 2006). We thus hypothesize:

H3: Hedonic user values have a significant and positive effect on check-in frequency.

H4: Hedonic user values have a significant and positive effect on loyalty to a specific check in application. 
Symbolic consumption behaviour in Levy (1959)'s definition is buying things not only for their functions, but also for what they mean and symbolize and the value they offer. In other words, the product or service symbolizes something different to them like being accepted to a social class or a certain group and have social meanings that give the feeling of belongingness to a social group or to a certain lifestyle (Mason, 1981; Levy, 1959; Belk, 1985, 1988). In this study, symbolic values are expected to increase check-in frequency and loyalty to a check-in application, because the places that people check-in can be a symbol of their lifestyles and tastes. It is already known that people prefer to check in at nice, popular, interesting, or luxury places to show others that they are socially and economically independent and available to go those places (Lindqvist et al., 2011; Barkhuus et al., 2008; Brown et al., 2007). Check-ins are done to perform and enhance oneself in the society since social media platforms make it possible to construct identities that they think is appropriate for themselves and for the audience (Cramer et al., 2011).Thus:

H5: Symbolic user values have a significant and positive effect on check-in frequency.

H6: Symbolic user values have a significant and positive effect on loyalty to a specific check in application.

\subsection{Impact of Familiarity on Check-in Behaviour}

In marketing literature familiarity is described as "how much a person knows about the product and how much a person thinks he knows about the product" (Park and Lessig, 1981, p. 223). Another definition is that product familiarity is an estimated result of various product related experiences in terms of consumers' cognitive structures (Marks and Olson, 1981), and individuals that have greater familiarity show higher loyalty (Flavián et al., 2007). Thus, Casalo et al. (2007) study shows that individuals that have greater familiarity show higher loyalty to websites they visit. A similar effect can be proposed for check-in applications.

Familiarity with a product or service is an important indicator of consumer behaviour, decreasing time and research cost, increasing usage amount and loyalty (Kotler and Armstrong, 2013; Wu et al., 2012). It is believed that familiarity will also extend its influence over social media usage.

Thus:

H7: Familiarity has a significant and positive effect on check-in frequency.

H8: Familiarity has a significant effect on loyalty to a specific check in application.

\subsection{Impact of Socialiability on Check-in Behaviour}

Socialiability and social interactions have been studied by psychologists and sociologists since very old times tracing back to Simmel (1949)'s studies. Cheek and Buss (1981) define socialiability as the tendency to affiliate and prefer being with others. The interactions and relations that people have with other people and their social environment are composing their social capital, which 
according to Field (2008) shows a person's socialiability level. As the number of people he/she knows and the amount of information he/she shares with others increase, the richer he/she is in social capital, the more social the person is. According to Tang et al. (2010), location sharing is motivated by social capital. Brown et al. (2007) consider location sharing as a social negotiation with people that you share your location with. Joinson's (2008) study shows that socialiability is an important motivation to use and be a part of social networks such as location sharing. Thus:

H9: Socialiability has a significant and positive effect on check-in frequency.

H10: Socialiability has a significant and positive effect on loyalty to a specific check in application.

\section{Methodology}

\section{Sample and Data Collection}

The population of the study is all mobile check-in application users in Istanbul. Due to time and monetary constraints, sampling was used. The sample of this study consisted of 500 individuals among people using mobile check-in applications. For the study convenience sampling method was preferred as it is fast, readily available and cost effective. A structured questionnaire was utilized to collect data between May 2013 and June 2013 through face to face interviews. The sample size was determined taking into account the data analysis technique. In this study Structural Equation Modeling (SEM) is used and the proper sample size for SEM is dictated by some factors affecting sample size requirements like misspecification, model size, departures from normality and estimation procedure. For this study model size sampling is used which has a 10:1 ratio. The survey questionnaire has 50 variables so a 500 or over sample size is required to have a valid result from SEM thus this study has a sample size of 500 .

The sample consisted of respondents whose age range was 25 to 28 . The gender distribution of the sample was 249 female (53\%) and 243 male (47\%) respondents. Most preferred check-in application is Facebook Check-in with $69.4 \%$ and Foursquare (4s) followed by $12.4 \%$.

\section{Model and Measures}

As given in Figure 1, the research model involves five major dimensions and each dimension is measured by scales taken from extant literature.

Commitment dimension of Lastovicka and Gardner (1979)'s Components of Involvement (CP) scale was used to measure consumer loyalty towards a specific check-in application. Check-in frequency was measured by asking people 'how often do you use mobile check-in applications?' and converting the variable to a five-point Likert-type scale. Two different scales were adapted to measure utilitarian values and hedonic values: HED/UT scale that measures user attitude towards mobile information services developed by Spangenberg et al. (1997) and Lindqvist et al. (2011)'s scale measuring 'why do people check-in'. To measure symbolic values that users provide from 
check-in activities, the Conspicuous Consumption Orientation Scale (CCO) of Chaudhuri et al. (2011) was paraphrased and the statements were adapted for mobile check-in activity. Familiarity with check-in applications was measured using the scale of Components of Involvement (CP) developed by Lastovicka and Gardner (1979). To measure socialiability of the respondents, Cheek and Buss (1981)'s socialiability scale, Leary et al. (2003)' scale of 'desire for social contact', Cohen (1967)'s CAD scale (Interpersonal Orientation) and Gosling, Rentfrow and Swann's (2003) Personality Inventories scale were used and adapted for check-in activity. For the scales, a backtranslation technique was used to establish meaning consistency (Brislin, 1990). The scales were first translated into Turkish, and then back into English and they were checked by a language professor.

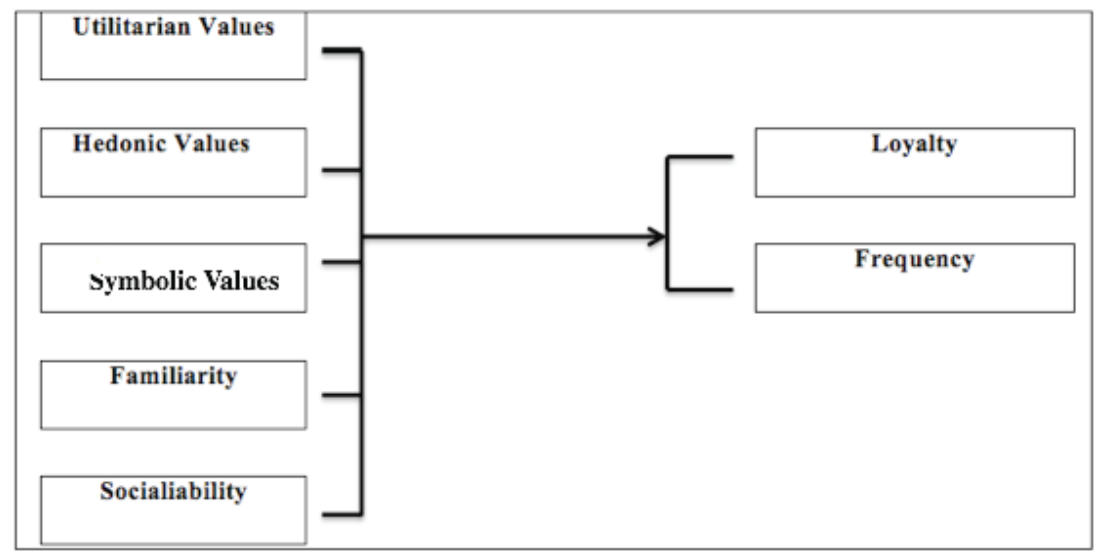

Figure I: Proposed Research Model

\section{Research Findings}

\section{Sample Profile and Behavioral Tendencies of the Sample}

Descriptive statistics shows the profile of the sample in terms of age, gender, education level. The sample mostly consists of the respondents who are aged between 17-25 age group. Also the respondents whose ages are between 25-30 present the second big part of the sample.

Gender profile consists of 249 female and 243 male respondents which is a good distribution. Also, $78 \%$ of the respondents are university students who are at graduate level.

When looking at the behavioural tendencies of the sample, statistics show that respondents use Internet almost all the time and every day and most preferred check-in application is Facebook's check-in application with $69,4 \%$. Foursquare (4s) follows Facebook with 12,4\% and Twitter comes third with $4,6 \%$.

Check-in frequency of respondents shows that most of the respondents check-in often (32\%), the number of respondents who claim that they check-in sometimes and always are almost equal with $26 \%$. 


\section{Reliability and Validity}

Reliability was conducted via SPSS 21 and the results are satisfactory. Reliability was evaluated by assessing the internal consistency of the items representing each factor using Cronbach Alpha. It is good for a reliable scale to exceed the minimum standard of 0.80 or 0.76 reliability (Marsh and Hocevar 1988, Wang and Tang, 2003).

Table I: Reliability and Composite Reliability of Scales

\begin{tabular}{|l|c|c|}
\hline Dimensions & Cronbach's alpha & Composite Reliability \\
\hline Hedonic/Utilitarian Values & 0.919 & 0.86 \\
\hline Symbolic Values & 0.938 & 0.92 \\
\hline Familiarity & 0.903 & 0.80 \\
\hline Loyalty & 0.847 & 0.89 \\
\hline Socialiability & 0.876 & 0.85 \\
\hline
\end{tabular}

The study is valid for convergent validity because the items under the factors have significant factor loadings (Gefen and Straub, 2005; Fornell and Larcker, 1981; Farrell and Rudd, 2009) and is valid in terms of content validity as well because all items in this study are measured by reliable and commonly used scale items in marketing literature (Carmines and Zeller, 1979). This study is also valid in terms of discriminant validity because all the AVE (avarage variance extracted) scores are higher than 0,5 and square roots of AVE are higher than all the correlations of factors (Gefen and Straub, 2005). For example, for F1, AVE is 0,541 which is higher than 0,5 and square root of AVE is 0,734 which is higher than all correlations of F1.

Table 2: AVE and Square Root of AVE

\begin{tabular}{|c|c|c|c|c|c|c|c|}
\hline \multicolumn{5}{|c|}{ Correlation Matrix } & \multirow{2}{*}{\multicolumn{2}{|c|}{ AVE }} & \multirow{2}{*}{ Sq.R.AVE } \\
\hline & $\mathrm{F} 1$ & $\mathrm{~F} 2$ & F3 & F4 & & & \\
\hline F1 (uti-hedo) & * & 0,637 & 0,637 & 0,138 & F1 & 0,541 & 0,734 \\
\hline F2 (symbolic) & & * & 0,615 & $-0,053$ & F2 & 0,790 & 0,888 \\
\hline F3(familiarity) & & & * & $-0,052$ & F3 & 0,666 & 0,812 \\
\hline F4 (socialiability) & & & & * & F4 & 0,800 & 0,894 \\
\hline F5 (loyalty) & & & & & F5 & 0,660 & 0,812 \\
\hline
\end{tabular}




\section{EFA - CFA Results}

Exploratory factor analysis (EFA) was conducted with SPSS 21 including all the items measured: Hedonic, Utilitarian and Symbolic values, Familiarity, Socialiability and Loyalty. The items that have low communality (under 0.5 ) were eliminated (3 items from Utilitarian-Hedonic, 2 items from Socialiability, 1 item from loyalty scales were eliminated) because low communalities are suspected of low explanatory power (Hair et al., 1998; Warner, 2007; Costello and Osborne, 2005; Velicer and Fava, 1998). In EFA, five factors were extracted with the hedonic and utilitarian values grouped under the same factor. KMO (Kaiser-Meyer-Olkin) measure of sampling adequacy score for EFA is 0.946 which indicates good fit (Field, 2000; Pedhazur, 1991). EFA was also conducted for each dimension separately and each dimension gives the fit above 0.9 .

In CFA (Confirmatory Factor Analysis), five factors were extracted from EFA previously as Utilitarian-Hedonic values (F1), Symbolic values (F2), Familiarity (F3), Socialiability (F4) and Loyalty (F5) were inserted into path diagrams by using Amos 21 and the analysis was run. Model fit summary for CFA gave the measures of baseline comparisons like CFI (0.958), NFI (0.938), RFI (0.909), IFI (0.958) and TLI (0.938) which indicate good fit (Hooper et al. 2008, Hair et al. 1998, Bollen and Long 1993). RMSEA was satisfactory with 0,062 and Hoelter's critical N was significant being 0.05 and 0.01(Hair et al., 1998).

Table 3: EFA and CFA Factor Loadings

$\begin{array}{llr}\text { rian/Hedonic Values } & \text { U2: I check-in to inform about what I am currently doing. } & 0,683 \\ \text { VE=14,59, CR=0,86, Vextr=0,54) } & \text { U6: I check-in to tag my friends. } & 0,641 \\ & \text { H1: Checking-in is fun. } & 0,697 \\ & \text { H3: I check-in to track people. } & 0,624 \\ & & \\ & \text { C5: I check-in at trendy places. } & 0,663 \\ \text { Jlic Values } & \text { C6: My check-ins show my original taste of living. } & 0,671 \\ \text { VE=13,55, CR=0,92, Vextr=0,79) } & \text { C7: My check-ins reflect my personality } & 0,799 \\ & & \\ \text { arity } & \text { FM2: I can compare check-in applications with each other. } & 0,691 \\ \text { VE=9,8, CR=0,80, Vextr=0,66) } & \text { FM4: I have a knowledge about check-in applications. } & 0,755 \\ & & \\ \text { y } & \text { L2: I am committed to my check-in application. } & 0,603 \\ \text { VE }=9,7, C R=0,89, \text { Vextr=0,80) } & \text { L3: I will keep using my check-in application. } & 0,743 \\ & \text { L4: I recommend my check-in application to others. } & 0,588\end{array}$




\section{SEM Results}

Utilitarian-Hedonic values (F1), Symbolic values (F2), Familiarity (F3) and Socialiability (F4) that build the independent variables of the study were drawn in the structured model on Amos 21 by adding "frequency" and Loyalty (F5) as dependent variables. The model fit measures for SEM model are acceptible as CFI (.958), NFI (.938), RFI (.909), IFI (.958) and TLI (.938) all show good fit (Hooper et al., 2008; Hair et al., 1998; Bollen and Long, 1993). RMSEA is satisfactory with 0,062 and Hoelter's critical $\mathrm{N}$ is significant as expected being 0.05 and 0.01(Hair et al., 1998).

The hypotheses are discussed by looking at the significances and weights of the relationships. Only $\mathrm{H} 9$ is rejected, indicating that socialiability does not have a significant effect on frequency of check-ins. $\mathrm{H} 1(\beta=-0,16), \mathrm{H} 3(\beta=-0,16), \mathrm{H} 5(\beta=-0,17)$ are partially and $\mathrm{H} 7(\beta=0,87)$ is fully accepted. Thus, utilitarian, hedonic, conspicuous values have significant, but negative effects on frequency of check-ins. Familiarity, on the other hand, exerts a signifcant positive effect on frequency of check ins. $H 2(\beta=0,3), H 4(\beta=0,3), H 6(\beta=0,12), H 8(\beta=0,32), H 10(\beta=0,10)$ are all accepted, meaning that utilitarian, hedonic, conspicuous values, familiarity and socialiability have significant and positive effects on loyalty to a specific check-in application. The squared multiple correlations of dependent variables show that loyalty explains $58 \%$ and frequency explains $48 \%$ of the structured model.

Table 4: SEM Results

\begin{tabular}{|c|c|c|c|c|}
\hline \multicolumn{2}{|r|}{ Relationships } & \multirow{2}{*}{$\begin{array}{c}\mathbf{P} \\
* * *\end{array}$} & \multicolumn{2}{|c|}{ St. Estimates Hypothesis } \\
\hline Loyalty & $<---$ Sociability & & 0,1 & H10-Accepted \\
\hline Loyalty & $<---$ Familiarity & $* * *$ & 0,32 & H8-Accepted \\
\hline Loyalty & $<---$ Symbolic Values & $* * *$ & 0,12 & H6-Accepted \\
\hline Loyalty & <--- Utilitarian-Hedonic Values & $* * *$ & 0,3 & H2,H4-Accepted \\
\hline Frequency & $<---$ Sociability & 0,956 & $-0,02$ & H9-Rejected \\
\hline Frequency & $<---$ Familiarity & $* * *$ & 0,87 & H7-Accepted \\
\hline Frequency & $<---$ Symbolic Values & $* * *$ & $-0,17$ & H5-Partially Accepted \\
\hline Frequency & $<---$ Utilitarian-Hedonic Values & $* * *$ & $-0,16$ & H1,H3-Partially Accepted \\
\hline & $\begin{array}{r}\qquad * *=\text { Significant } \\
\text { Squared Multiple Correlatio }\end{array}$ & $\begin{array}{l}0,05 \\
\text { loya }\end{array}$ & ficance & ncy: 0,483 \\
\hline
\end{tabular}

\section{Discussion and Implications}

Mobile marketing is one of the newest developments in marketing and is growing in importance, offering many different tools for the utilization of marketers. Customer behaviour is also rapidly evolving in the mobile environment with the advent of mobile devices and $7 / 24$ outreach 
of the Internet. Thus these developments force marketers to invest in marketing initiatives to communicate with and build relationships with customers in the mobile environment. However, still little is known for what drives consumer behaviour in the mobile environment. This paper addresses this gap and tries to explore the drivers of frequency of check-in and loyalty to check-in applications, a widespread tool of mobile location based services. Drawing from uses and gratifications theory, the proposed model includes utilitarian, hedonic and symbolic values as motivations to use the application. Additionally, it incorporates familiarity with check-in applications and socialiability as personality characteristics in the model. Thus, it proposes a comprehensive model to understand check-in frequency and loyalty to check-in application. The findings provide interesting insights to our understanding, and offer cues for strategy development for check-in application creators and venue marketers.

The main finding of the research is that consumers tend to use and become loyal to check-in applications mainly because of familiarity with the application. In other words, people tend to use "check-in applications" as they become aware of them, know and use them. Thus, businesses have to break the ice between themselves and the check-in applications and start to use the application in the first place. Loyalty and usage rate increases directly with usage. This finding implies the need for awareness communications and initial trial promotions. An interesting finding of the research was the merge of the utilitarian and hedonic motivations into one component. This joint factor had an effect on both frequency of and loyalty to check-in applications. The reason for this outcome may be linked to the specific characteristics of location sharing services what requires functionality of the service mix with hedonic characteristics (Cramer et al.., 2011). Check-in is like gaming, what produces an entertaining effect even when it is used for functional purposes. Therefore, the utilitarian and hedonic values may have merged in this research.

An important finding of the study is that utilitarian-hedonic values and symbolic values both negatively affect check-in frequency even though their effect on loyalty to a check-in application is positive. As people seek more utilitarian-hedonic or symbolic benefits in venues, they tend to check-in less or check-in selectively. This might be a result of consumers' thinking that not all places produce utilitarian-hedonistic or symbolic benefits to them. Cramer et al. (2011)'s study shows similar results that some people act selectively and tend to check-in at places that seem interesting to them and try to minimize annoyance to others caused by uninteresting check-ins. Lindqvist et al. (2011) also pointed out that people often found it more reasonable to check-in at places that were new, unique, and non-routine. Places, such as fast-food restaurants were not interesting or worthy to check-in since they were not impressing to others; some people were even embarrased to check-in at those places. Most people also did not prefer to check-in at places such as work or home because it was both routine and non-interesting, and also private.

On the other hand, both utilitarian-hedonic, symbolic values and also the socialiability characteristic have a positive effect on loyalty to check-in applications. People tend to stick to the same application probably because they want to socialize with the same group of people who also use the same check-in application. Check-in application becomes a platform where the same 
people meet and show each other where they go, what they eat or do. In a way the activities they perform on the application form the identity they want to communicate to their social circle. Therefore, it is important that the same application (which is used by their friends) is utilized each time they check-in. The utilitarian-hedonic benefits also drive loyalty to a check-in application. Thus, joy, variety of actions, information reach and other functions are key in forming positive attitudes and behaviour towards a check-in application.

Implications for mobile marketers: This study shows that drivers of frequency of check-in and loyalty to a specific check-in application may change from each other even though familiarity is depicted as the most important driver for both. Thus, application producers should work better to communicate their application to users and induce initial trial. Utilitarian-hedonic values elevate check-in application loyalty. Thus, it is important to include fun, engaging, and socializing factors in the application services. Socialiability and symbolic values also have an impact on check-in application loyalty. Thus, partnerships with other social media platforms to communicate check-in status or learn about others may be essential for check-in application creators. They may as well focus on customized applications that people from several different social groups can use according to their preferences. Some people may prefer to see the ideas and tastes of others in the same social or cultural group, thus a customized application (based on segmentation) which allow people to create groups and to be a member of the groups that they feel close with can be useful. This may also increase the loyalty to the applications.

For venue marketers: Since it is understood that familiarity is an important factor for people to use check-in applications, it is expected that in the future when the awareness and familiarity towards check-in applications increase, people will use them more. Research shows that the consumergenerated content and reviews assist the online buying process, acting like a re-intermediary between the firm and consumers since they become a major way to learn about company offerings (Ahearne and Rapp, 2010; Branes, 2014). Thus the venue marketers or managers should consider the importance of check-in applications, and the user generated reviews, ratings etc., related to their brand. People use the check-in services like a public forum, whereby consumers can raise their own voices and also listen up other product information that affects their purchase decisions. Thus, businesses like restaurants should also be conscientious about their staff and services given the fact that check-in and leaving tips, reviews may increase in the future. People in marketing and operating of locations should follow the check-ins of people and their preferences from several check-in applications, therefore they may create strong customer relationships. For example, they may differentiate themselves on specific meals or drinks by looking at the favourites of people.

Businesses should also encourage location sharing and may award positive reviewers or mayors among the users. Awareness and familiarity is needed to induce check-in activity. Hence, businesses may offer offline campaigns to encourage check-in and reward consumers who check-in online. Hedonic and utilitarian motivations stand out as strong drivers of check in behaviour. Thus, check-in campaigns related to fun and socialization may also work well to increase check-in 
frequency. Interestingly, symbolic values are negatively related to check-in frequency. Venue owners should emphasize uniqueness and originality (in terms of menu, location, staff, ambiance etc.) in their communications so that people do not view them as a third place alternative to work and home, but view as interesting and attractive enough to share their presence to friends in online environments.

\section{Limitations of the Study and Implications for Further Research}

This study was based on self-reported survey results, research based on actual past behavioural history of the participants could provide more accurate results, coupled with patterns that are not possible with survey data. This study also considered frequency of check-in behaviour. Other research may elaborate this subject further by studying motivations taking into consideration where people check-in, as well as which activities they do on LBS application (such as earning badges, liking other people's check-ins, commenting etc.).

Because of the budget and time limitations, convenience sampling method was used for the study which creates difficulties for generalizability of the study.

In addition to this, the study is conducted to 500 respondents consisting mostly of university students in Istanbul, therefore it may not totally be representative of the population. Even though the study catches the check-in users in the world in terms of demographics, it is not representative worldwide because of cultural and economic differences with other countries.

The study also has several implications for researchers who will study the same or similar subjects in the future. Because the study involves consumer behaviour dimensions, focus group studies and in-depth interviews are highly recommended to understand users' feelings and insights deeply. Further studies should also observe the respondents' social environment well. The attitudes toward check-in applications, popularity of check-in applications in that environment should be considered. Cultural, economic and social situations of people can be considered while measuring the motivations of check-in behaviour.

\section{References}

Ahearne, Michael, and Adam Rapp (2010). The Role of Technology at the Interface Between Salespeople and Consumers. Journal of Personal Selling \& Sales Management, 30 (2), 109-118.

Barnes, N. (2014). Social Commerce Emerges as Big Brands Position Themselves to Turn 'Follows' 'Likes' and 'Pins' into Sales, Marketing Management Association Annual Spring Conference Proceedings, Chicago, IL, March 26-28, 2014, 8-13.

Barkhuus Louise, Brown Barry, Bell Marek, Hall Malcolm, Scott Sherwood, Matthew Chalmers. (2008). From Awareness to Repartee: Sharing Location within Social Groups. In Proc. of CHI.

Bauer H.H., T. Reichardt, S.J. Barnes, M.M. Neumann. (2005). Driving consumer acceptance of mobile marketing: A theoretical framework and empirical study. Journal of Electronic Commerce Research, 6 (3), pp. 181-192. 
Bazerman, M. H., Tenbrunsel, A. E., Wade-Benzoni, K. (1998). Negotiating with Yourself and Losing: Making Decisions with Competing Internal Preferences. Academy of Management Review, 23(2), 225-241.

Blanchflower, T.M and Watchraveravesringkan, K.T. (2014). Exploring the Impact of Social Networking Sites on Brand Equity. Marketing Management Association Spring 2014 Conference, Proceedings Book, 20-24

Bollen Kenneth A. and Long J. Scott. 1993.Testing Structural Equation Models.

Brislin, R. W. (1990). Applied Cross-Cultural Psychology. Newbury Park, CA:Sage.

Brown, B., Taylor, A., Izadi, S. et al. (2007). Locating family values: a field trial of the whereabouts clock, In Proc. UbiComp'07, ACM Press, 354-371.

Bruner II, G. C., and A. Kumar. (2005). Explaining consumer acceptance of handheld Internet devices. Journal of Business Research 58 (5): 553 - 558.

Casalo, L., Flavian, C., and Guinaliu, M. (2007). The impact of participation in virtual brand commuities on consumer trust and loyalty. Online Information Review, 31 (6), 775-792

Chaudhuri H.R., Mazumdar S. and Ghoshal A. (2011). Conspicuous consumption orientation: Conceptualisation, scale development and validation. Journal of Consumer Behaviour, J. Consumer Behav. 10: 216-224

Cheek, J. M. and Buss, A. J. (1981). Shyness and Socialiability. Journal of personality and social psychology, $41,330-339$.

Chen E.Y.I., Yeh N-C, Wang C. P. (2008). Conspicuous Consumption: A Preliminary Report of Scale Development and Validation. Advances in Consumer Research, Volume 35

Chiou, J.S. (2004). The antecedents of consumers' loyalty toward Internet Service Providers. Information \&Management, 41(6), 685-695

Cohen, Joel B. (1967). An Interpersonal Orientation to the Study of Consumer Behavior. Journal of Marketing Research, 4 (August), 270-278.

Consolvo S., Ian S., , LaMarca A., Hightower J., Scott J., Sohn T., Hughes J., Iachello G., and Abowd G.D. (2005). Social Disclosure of Place: From Location Technology to Communication Practices. Proceedings of the 3rd International Conference on Pervasive Computing

Costello A.B. and Osborne J.W. (2005). Best Practices in Exploratory Factor Analysis: Four Recommendations for Getting the Most from Your Analysis. Practical Assessment, Research \& Evaluation, Volume 10 Number 7

Dhar R. and Wertenbroch K. (2000). Consumer Choice Between Hedonic and Utilitarian Goods. Journal of Marketinf- Research Vol, XXXVll,60-71

Farrell A.M. and Rudd J.M. (2009). Factor Analysis and Discriminant Validity: A Brief Review of Some Practical Issues", Australia-New Zealand Marketing Academy Conference (ANZMAC), December, Melbourne, Australia Field John. 2008. Social Capital.

Fornell C. and Larcker D.F. (1981). Evaluating Structural Equation Models with Unobservable Variables and Measurement Error. Journal of Marketing Research, Vol. 18, No. 1 (Feb.), pp. 39-50

Goff R., http://www.socialmediaexaminer.com/location-based-services-foursquare-vs-facebook-places/ (accessed 24.10.2011)

Gefen D. and Straub D.W. (2005). Practical Guide to Factorial Validity Using PLS-Graph: Tutorial and Annotated Example. Communications of AIS, 16 (1), 91-109.

Gosling Samuel D., Peter J. Rentfrow, and William B. Swann Jr. (2003). A very brief measure of the Big-Five personality domains. Journal of Research in Personality 37 504-528

Hair J. F., Tatham R.L., Anderson R. E., Black W. 1998. Multivariate Data Analysis (5th Edition). 
Hanzaee K.H., Norouzi A. and Ghalandari K. (2011). The Effect of İnvolvement On Utilitarian and Hedonic Products Knowledge. World Applied Science Journal 13 (7): 1635-1642

Holbrook, Morris B. and Elizabeth C. Hirschman. (1982). The experiential aspects of consumption: Consumer fantasies, feelings, and fun. Journal of Consumer Research, 2 (September), 132-140

Hooper D., Coughlan J., and Mullen M.R. (2008). Structural Equation Modelling: Guidelines for Determining Model Fit. Electronic Journal of Business Research Methods, Volume 6 Issue 1

Humphreysa L. and Wilkenb R. (2015). Social media, small businesses, and the control of information. Information, Communication \& Society. Volume 18, Issue 3, Special Issue: AoIR Special Issue

Joinson A.N. (2008). Looking at', 'Looking up' or 'Keeping up with' People? Motivates and Uses of Facebook. CHI, April 5e10, Florence, Italy

Katz, E., Blumler, J.G. and Gurevitch, M. (2011). Uses and Gratifications Research.The Public Opinion Quarterly 4th ser. 37 (1973-1974): 509-23. JSTOR. Web. 14 Oct

Keller K.L. (1993). Conceptualizing, measuring and managing customer-based brand equity". Journal of Marketing 1993, 57 (1): 1-22.

Kleijnen Mirella, Ruyter de Ko, Wetzels Martin. (2007). An assessment of value creation in mobile service delivery and the moderating role of time consciousness. Journal of Retailing 83, 33-46

LaRose R., Eastin M.S. (2004). A Social Cognitive Theory of Internet Uses and Gratifications: Toward a New Model of Media Attendance. Journal of Broadcasting \& Electronic Media, Volume 48, Issue 3 October, pages $358-377$

Lastovicka John L. and Gardner David M. (1979). Components of Involvement. In John C. Maloney and Bernard Silverman (eds.), Attitude Research Plays for High Stakes. Chicago: American Marketing Association, pp. 5373.

Leary M.R., Kenneth H.C., McCrarya F. (2003). Finding pleasure in solitary activities: desire for aloneness or disinterest in social contact? Personality and Individual Differences 35, 59-68

Levy S.J. (1959). Symbols for Sale. Harvard Business Review, 37 (July-August), 117-119

Lindqvist J., Cranshaw J., Wiese J., Hong J. and Zimmerman J. (2011). I'm The mayor of My House: Examining Why People Use Foursquare- a Social Driven Location Sharing Application. CHI 2011, May 7-12, Vancouver, BC, Canada

Ludford P.J., Reid P., Ken R., Loren T. (2007). Capturing, Sharing and Using Local Place Information. Location Aware Systems CHI Proceedings, San Jose, CA, USA, April 28 May 3

Marks Larry J. and Olson J.C. (1981). Toward a Cognitive Structure Conceptualization of Product Familiarity. In NA - Advances in Consumer Research Volume 08, eds. Kent B. Monroe, Ann Abor, MI: Association for Consumer Research, Pages: 145-150

Marsh H.W., and Hocevar D. (1988). A new, more powerful approach to multitrait-multimethod analyses: Application of second order confirmatory factor analysis. Journal of Applied Psychology, 73, 107117

Muntinga, D.G., Moorman, M. and Smit, E.G. (2011). Introducing COBRAs: Exploring Motivationds for Brand-related Social Media Use. International Journal of Advertising, 30(1), 13-46

Naaman, M., Boase, J. and Lai, C. 2010. Is it Really About Me? Message Content in Social Awareness Streams. In Proc. CSCW '10, ACM Press, 189-192.

Olli T. Ahtola (1985). Hedonic and Utilitarian Aspects of Consumer Behavior: An Attitudinal Perspective”, in NA - Advances in Consumer Research Volume 12, eds. Elizabeth C. Hirschman and Moris B. Holbrook, Provo, UT: Association for Consumer Research, Pages: 7-10

Oloo, F.L. 2013. Intagratification: Uses and Gratification of Instagram by University Students for Interpersonal Communication. Master of Arts thesis, Eastern Mediterranean University, North Cyprus 
Park C.W. and Lessig V.P. (1981). Familiarity and It's Impact on Decision Biases and Heuristics. Journal of Consumer Research, 8 (September), 223-230

Park CW., Jaworsky B.J., MacInnis D.J. (1986). Strategic brand concept-image management”, Journal of Marketing, vol 50, October 1986

Park, J. and SuJin, Y. (2006). The moderating role of consumer trust and experiences: Value driven usage of mobile technology. International Journal of Mobile Marketing, 1(2), 24-32

Pitta Dennis A. (2011). Location-based social networking and marketing. Journal of Consumer Marketing, Vol. 28 Iss: 2, pp.

Rai R., (2011). Shyness and socialiability re-examined: Psychometrics, interactions, and correlates". Open Access Dissertations and Theses Paper 5723

Santesso D.L., Schmidt L.A., Fox N.A. (2004). Are shyness and socialiability still a dangerous combination for substance use? Evidence from a US and Canadian sample. Personality and Individual Differences $37,5-17$

Scellato, S., Noulas, A., Lambiotte, R., Mascolo, C. (2011). Socio-spatial Properties of Online Location-based Social Networks, In Proc. ICWSM'11

Simmel G. (1949). The Sociology of Socialiability. The American Journal of Sociology [AJS], 55(??), 254 261.

Spangenberg Eric R., Kevin E. Voss, and Ayn E. Crowley. (1997). Measuring the Hedonic and Utilitarian Dimensions of Attitude: a Generally Applicable Scale. In NA - Advances in Consumer Research Volume 24, eds. Merrie Brucks and Deborah J. MacInnis, Provo, UT: Association for Consumer Research, Pages: 235-241

Stone, G., Singletary, M.W., Richmond, V.P. (1999). Clarifying Communication Theories: A Hands-on Approach: Wiley-Blackwell.

Strahilevitz M, Meyers JG. (1998). Donations to charity as purchase incentives: how well they work may depend on what you are trying to sell. Journal of Consumer Research, 24:434- 46

Tang K. P., Lin J., Hong J.I., Siewiorek D.P., Sadeh N. (2010). Rethinking Location Sharing: Exploring the Implications of Social Driven vs. Purpose Driven Location Sharing. UbiComp 2010, Sep 26 - Sep 29, Copenhagen, Denmark

Varnalı K., Toker A. (2010). Mobile marketing research: The-state-of-the-art. International Journal of Information Management, 30:2, 144-151

Velicer, W. F., and Fava, J. L. (1998). Effects of variable and subject sampling on factor pattern recovery. Psychological Methods, 3(2), 231-251

Vrocharidou, A. And Efthymiou, I. (2012). Computer Mediated Communication for Social and Academic Purposes: Profiles of Use and University Students' Gratifications. Computers and Education, 58 (1), 609-616

Wadman R., Durkin K., Conti-Ramsden G. (2008). Self-Esteem, Shyness, and Socialiability in Adolescents with Specific Language Impairment (SLI)', Journal of Speech, Language, and Hearing Research, Vol. 51, 938-952, August

Wang E.S. and Tang T.I. (2003). Assessing customer perceptions of Web sites service quality in digital marketing environments. Journal of End User Computing, 15(3), 14-31

Warner, R. M. (2007). Applied statistics: From bivariate through multivariate techniques. SAGE Publications, Thousand Oaks, CA, $1128 \mathrm{p}$.

http://www.tk.gov.tr/kutuphane_ve_veribankasi/pazar_verileri/ucaylik12_4.pdf(accessed 07.05.2013)

http://www.pewinternet.org/ /media//Files/Reports/2010/PIPLocation\%20based\%20services.pdf (accessed 07.05.2013)

http://mashable.com/2011/05/04/social-location-apps-study/ (accessed 24.10.2011) 
